\title{
BEBAN KERJA PERAWAT DALAM PELAKSANAAN MANAJEMEN TERPADU BALITA SAKIT DI PUSKESMAS WILAYAH KERJA DINAS KESEHATAN KABUPATEN BANDUNG
}

\author{
Dewi Mustikaningsih; Rahmat; Rina Frastika \\ STIKes Aisyiyah Bandung \\ Jalan KH. Ahmad Dahlan (Banteng Dalam ) No.6 Bandung \\ Email : aning klw@ymail.com
}

\begin{abstract}
ABSTRAK
Manajemen Terpadu Balita Sakit digunakan sebagai standar pelayanan sekaligus sebagai pedoman pelayanan bagi tenaga kesehatan khususnya di Fasilitas Pelayanan Kesehatan Dasar, namun pelaksanaan ini belum di ketahui dikarenakan adanya beberapa faktor yaitu faktor pengetahuan dari tenaga kesehatan bervariasi ada petugas yang mendapat pelatihan dan tidak, beban kerja dari tenaga kesehatan karena jumlah pasien tidak menentu serta tidak seimbangnya jumlah pasien dengan tenaga kesehatan yang ada. Beban kerja adalah sejumlah kegiatan yang harus diselesaikan oleh suatu unit organisasi atau pemegang jabatan secara sistematis. Penelitian ini bertujuan untuk mengetahui tingkat beban kerja Perawat dalam pelaksanaan manajemen terpadu balita sakit di Puskesmas Wilayah Kerja Dinas Kesehatan Kabupaten Bandung. Metode penelitian ini menggunakan metode deskriptif dengan pendekatan kuantitatif dan desain cross sectional. Tehnik pengambilan sampel menggunakan stratified random sampling dengan besar sampel 36 responden dan analisis data yaitu analisa univariat. Hasil penelitian didapatkan gambaran beban kerja berdasarkan target yang harus dicapai dikategorikan sedang (44,4\%), kondisi pekerjaan dikategorikan tinggi $(47,2 \%)$, penggunaan waktu kerja dikategorikan tinggi $(75,0 \%)$, standar pekerjaan dikategorikan tinggi $(38,9 \%)$ dan beban kerja perawat dikategorikan rendah $(36,1 \%)$. Kesimpulan penelitian bahwa tingkat beban kerja perawat dalam pelaksanaan manajemen terpadu balita sakitdi Puskesmas Wilayah Kerja Dinas Kesehatan Kabupaten Bandung dikategorikan sedang.
\end{abstract}

Kata kunci: beban kerja; manajemen terpadu balita sakit; perawat; puskesmas

\section{ABSTRACT}

Integrated Management of Sick Toddler is used as a service standard as well as a service guide for health workers especially in Basic Health Service Facilities, but this implementation has not been known due to several factors, namely the knowledge factor of health workers varies, there are officers who receive training and no workload from health workers because the number of patients is uncertain with health workers is not balanced. Workload is a number of activities that must be completed by an organizational unit or office holder systematically. The purpose of determine the level of nurse's workload in implementation integrated management of sick toddler. This research uses descriptive method with quantitative approach and cross sectional design. The sampling technique uses stratified random sampling with a sample size of 36 respondents with univariate analysis. The results showed that the picture of workload based on the target to be achieved was categorized as moderate (44.4\%), work conditions as high (47.2\%), use of work as high (75.0\%), work standards as high (38,9\%) and the workload of nurses as low (36.1\%). The conclusion is level of workload of nurses in the implementation of integrated management of sick toddler is categorized as moderate.

Keywords: health center; integrated management ofsick toddler; nurse; workload. 


\section{LATAR BELAKANG}

Manajemen terpadu balita sakit adalah suatu pendekatan yang digagas oleh WHO (World Health Organization) dan UNICEP (United Nation Childrens Fund) guna menyiapkan Perawat melakukan penilaian, membuat klasifikasi serta memberikan tindakan kepada anak terhadap penyakit-penyakit yang umumnya mengancam jiwa.

Manajemen terpadu balita sakit pertama kali diperkenalkan pada tahun 1999 untuk meningkatkan kemampuan Perawat. Manajemen terpadu balita sakit dalam kegiatan di lapangan khususnya di Puskesmas merupakan suatu sistem yang mempermudah pelayanan serta meningkatkan mutu pelayanan. Apabila di suatu Puskesmas menerapkan manajemen terpadu balita sakit berarti turut membantu dalam upaya pemerataan Pelayanan Kesehatan dan dapat membuka akses bagi seluruh lapisan masyarakat untuk memperoleh pelayanan kesehatan yang terpadu (Novitasari, 2011).

Manajemen terpadu balita sakit digunakan sebagai Standar Pelayanan sekaligus sebagai pedoman pelayanan bagi tenaga kesehatan (Bidan dan Perawat) khususnya di Fasilitas Pelayanan Kesehatan Dasar. Penerapan manajemen terpadu balita sakit yang efektif jika ibu atau keluarga serta membawa balita sakit ke Perawat yang terlatih sehingga dengan cepat dapat ditentukan pengobatannnya (Depkes RI: 2011). Namun dalam prakteknya manajemen terpadu balita sakit ini masih mengalami hambatan yang salah satunya dikarenakan keterampilan petugas. Tiga komponen dari manajemen terpadu balita sakit ditujukan untuk meningkatkan keterampilan Perawat dalam tatalaksana kasus balita sakit (selain dokter, Perawat non-dokter dapat pula memeriksa dan menangani pasien apabila sudah dilatih), memperkuat sistem kesehatan, dan meningkatkan kemampuan perawatan di rumah oleh keluarga dan masyarakat. (Novitasari, 2014)

Angka kematian bayi dan anak di dunia masih tinggi. Di negara berkembang hampir 10 juta kematian terjadi setiap tahun pada anak dibawah usia 5 tahun. Laporan United Nations Children's Fund (UNICEP) (2013) mengatakan di Indonesia jumlah kematian balita setiap tahun turun dari estimasi 12,6 juta pada tahun 1990 menjadi sekitar 6,6 juta pada tahun 2012, namun angka ini masih cukup tinggi. Angka kematian bayi adalah 34 per 1000 kelahiran hidup, sementara angka kematian balita adalah 44 per 1000 kelahiran hidup. Diharapkan pada tahun 2015 angka kematian bayi turun menjadi 23 per 1000 kelahiran hidup dan angka kematian balita turun menjadi 32 per 1000 kelahiran hidup. Pencapaian pada 2015 merupakan target komitmen global tujuan Milennium Development Goals (MDGs) (Kemenkes RI, 2010 dalam Novitasari, 2014).

Menurut Laporan tahunan Dinas kesehatan Kabupaten Bandung (2015) AKB (Angka Kematian Bayi) di Kabupaten Bandung pada tahun 2013 adalah $34,01 / 1000 \mathrm{KH}$ dan tahun 2014 adalah 33,9/1000 KH. Penurunan Angka Kematian Bayi dari tahun ke tahun, baik di Kabupaten Bandung maupun di Jawa Barat. Angka Kematian Bayi (AKB) di Kabupaten Bandung untuk tahun 2009 sampai dengan tahun 2014 masih menggunakan angka proyeksi, dan mulai tahun 2014 sudah dalam angkanya dan AKB (Angka Kematian Bayi) tahun 2014 menunjukan 33,9 AKB (Angka Kematian Bayi) tersebut mengalami penurunan bila dibandingkan tahun sebelumnya. Di Kabupaten Bandung jumlah kematian neonatal berdasarkan laporan tahun 2015 sebanyak 163 kasus dengan penyebab terbanyak BBLR 99, Asfiksia 15, sebab lain 29 kelainan kongenital 10 , sepsi 16 , trauma lahir 2 , dan tetanus neonatorum 1.

Berdasarkan hasil Riset Kesehatan dasar (RISKESDAS) capaian indikator pelayanan kesehatan anak balita tahun 2013 sebesar $70,12 \%$ dan itu berarti belum memenuhi target renstra pada tahun 2013 yang sebesar 83\%. Capaian indikator ini juga mengalami penurunan dibandingkan tahun 2012 yang sebesar 73,52\%. Capaian indikator menurut Provinsi juga menunjukkan bahwa sebagian besar provinsi di Indonesia memiliki capaian di bawah 83\%.

Berdasarkan studi pendahuluan peneliti pada 24 Maret 2017 sampai 3 april 2017 yang dilakukan oleh peneliti di Puskesmas Wilayah Kerja Dinas Kesehatan Kabupaten Bandung berdasarkan wawancara terhadap 8 Puskesmas. 4 puskesmas mengungkapkan bahwa pelaksanaan program belum berjalan dengan benar dan adanya keterbatasan dalam jumlah petugas, jumlah balita yang masuk ke Poli dalam 
satu bulan mencakup 300 sampai 400 balita dalam satu hari terdapat 9 sampai 10 balita yang ke poli manajemen terpadu balita sakit pada hari senin dan selasa jumlah balita 15 samapai 20 yang ke poli manajemen terpadu balita sakit.4 Puskesmas mengungkapkan ada beban kerja mulai dari jumlah balita dalam satu hari yang begitu banyak dan banyak tugas selain memeriksa balita yang ke poli manajemen terpadu balita sakit petugas harus melakukan pendokumentasian, pencatatan formulir manajemen terpadu balita sakit, pemberian obat, konseling diluar gedung Puskesmas.

Pencapaian manajemen terpadu balita sakit di 8 Puskesmas Wilayah Kerja Dinas Kesehatan Kabupaten Bandung belum mencapai target yaitu sebesar 100\%. Pencapaian target yang telah di capai dalam pelaksanaan manajemen terpadu balita sakit di Puskesmas Bojongsoang sebesar 65\%, Puskesmas Dayeuhkolot sebesar 90\%, Puskesmas Rancamanyar sebesar 80\%, Puskesmas Cangkuang sebanyak 75\%, Puskesmas Sumber Sari sebesar 90\%, Puskesmas Jelekong 70\%, Puskesmas Banjaran Kota Sebesar 65\%, Puskesmas Baleendah sebesar $80 \%$. Peneliti tertarik meneliti gambaran beban kerja perawat dalam pelaksanaan manajemen terpadu balita sakitdi Puskesmas Wilayah Kerja Dinas Kesehatan Kabupaten Bandung.

Tujuan penelitian untuk mengetahui beban kerja perawat dalam pelaksanaan manajemen terpadu balita sakitdi Puskesmas Wilayah Kerja Dinas Kabupaten Bandung.

\section{METODE}

Jenis penelitian menggunakan penelitian adalah metode deskriptif dengan pendekatan kuantitatif dan desain cross sectional. Penelitian yang dilakukan berdasarkan pengamatan sesaat secara bersamaan dan dalam waktu tertentu. Penelitian deskriptif kuantitatif dilakukan untuk mengetahui beban kerja Perawat dalam pelaksanaan manajemen terpadu balita sakitdi Puskesmas Wilayah Kerja Dinas Kesehatan Kabupaten Bandung.Uji validitas dilakukan di Puskesmas Banjaran Nambo di Poli manajemen terpadu balita sakitdilakukan pada 10 responden pada bulan Juni 2017. Hasil uji validitas kuesioner beban kerja dari 33 pertanyaan ada 25 pertanyaan yang valid yaitu pada Q1, Q2, Q3, Q4, Q6, Q8, Q9, Q10, Q11, Q14, Q15, Q17, Q18, Q20, Q21, Q22, Q23, Q24, Q25, Q26, Q27, Q28, Q29, Q32, Q33. Hasil uji validitas diperoleh nilai r hitung masing-masing pernyataan lebih besar dari $r$ tabel $(0,5494)$, maka kuesioner yang digunakan dalam penelitian ini dapat dikatakan sudah valid.

\section{HASIL}

Tabel 1. diatas menunjukkan bahwa Hasil frekuensi jawaban responden berdasarkan jenis kelamin menunjukkan bahwa seluruh responden berjenis kelamin perempuan yaitu sebanyak 36 responden (100\%).

Tabel 1. Distribusi frekuensi karakteristik berdasarkan jenis kelamin di Puskesmas Wilayah Kerja Dinas Kesehatan Kabupaten Bandung

\begin{tabular}{ccc}
\hline Jenis kelamin & Frekuensi & $\begin{array}{c}\text { Persentasi } \\
\text { (\%) }\end{array}$ \\
\hline Perempuan & 36 & 100 \\
\hline Total & 36 & 100
\end{tabular}

Sebaran distribusi frekuensi karakteristik responden berdasarkan tingkat pendidikan dapat dijelaskan pada table 2

Tabel 2.Distribusi Frekuensi Karakteristik Responden Berdasarkan Tingkat Pendidikan di Puskesmas Wilayah Kerja Dinas Kesehatan Kabupaten Bandung

\begin{tabular}{ccc}
\hline Pendidikan & Frekuensi & Persentase \\
\hline Diploma 1 & 5 & $13,9 \%$ \\
Diploma 3 & 26 & $72,2 \%$ \\
Diploma 4 & 5 & $13,9 \%$ \\
Sarjana & 0 & 0 \\
Total & 36 & $100.0 \%$
\end{tabular}

Karakteristik pendidikan terakhir pada hasil penelitian memperlihatkan bahwa karakteristik responden berdasarkan tingkat pendidikan yang terbesar yaitu Diploma 3 sebesar (72,2\%), Diploma 1 sebanyak (13,9\%), Diploma 4sebanyak(13,9\%).Latar belakang pendidikan merupakan salah satu faktor penting dari seorang karyawan untuk mendukung menjalankan pekerjaan nya. 
Mustikaningsih, et al,. Beban Kerja Perawat Dalam Pelaksanaan Manajemen Terpadu Balita....

SJKP, Vol. 6, No. 1, Juni 2019, 13-24

Tabel3. Distribusi Frekuensi Karakteristik Responden Berdasarkan Masa Kerja di Puskesmas Wilayah Kerja Dinas Kesehatan Kabupaten Bandung

\begin{tabular}{ccc}
\hline Masa Kerja & Frekuensi & Persentase (\%) \\
\hline 5-10 tahun & 14 & 38,9 \\
11-15 tahun & 5 & 13,9 \\
16-20 tahun & 4 & 11,1 \\
21-25 tahun & 5 & 13,9 \\
26-30 tahun & 7 & 19,4 \\
31-35 tahun & 1 & 2,8 \\
\hline Total & 36 & 100.0 \\
\hline Tabel $3 . \quad$ di atas & menunjukkan bahwa
\end{tabular}
Karakteristik masa kerja pada hasil penelitian memperlihatkan bahwa karakteristik responden berdasarkan masa kerja yang terbesar yaitu 5-10 tahun sebesar $(38,9 \%), 26-30$ tahun sebanyak (19,4\%), 11-15 tahun sebanyak (13,9\%). 21-25 tahun sebanyak (13,9\%), 16-20 tahun sebanyak $(11,1 \%), 31-35$ tahun sebanyak $(2,8 \%)$
Tabel. 4 Distribusi Frekuensi Karakteristik Responden Berdasarkan mengikuti pelatihan MTBS di Puskesmas Wilayah Kerja Dinas Kesehatan Kabupaten Bandung

\begin{tabular}{ccc}
\hline Pelatihan MTBS & Frekuensi & Persentase \\
\hline Ya & 12 & $33,3 \%$ \\
Tidak & 24 & $66,7 \%$ \\
\hline Total & 36 & $100.0 \%$
\end{tabular}

Tabel 4.di atas menunjukkan bahwa Karakteristik petugas yang mengikuti pelatihan manajemen terpadu balita sakit pada hasil penelitian memperlihatkan bahwa karakteristik responden berdasarkan petugas yang mengikuti pelatihan manajemen terpadu balita sakit yang terbesar yaitu petugas yang tidak mengikuti pelatihan manajemen terpadu balita sakit sebanyak 24 orang sebesar $(66,7 \%)$ dan petugas yang mengikut pelatihan manajemen terpadu balita sakit sebanyak 12 orang sebesar $(33,3 \%)$.

Tabel 5. Distribusi frekuensi gambaran bebankerja Perawat dalam pelaksanaan MTBSberdasarkan target yang harus di capaidi Puskesmas Wilayah Kerja Dinas KesehatanKabupaten Bandung

\begin{tabular}{|c|c|c|c|c|}
\hline Pernyataan & $\begin{array}{l}\text { STS } \\
(\%)\end{array}$ & $\begin{array}{l}\text { TS } \\
(\%)\end{array}$ & $\begin{array}{l}\text { S } \\
(\%)\end{array}$ & $\begin{array}{l}\text { SS } \\
(\%)\end{array}$ \\
\hline $\begin{array}{l}\text { Saya mampu menjalankan program MTBS yang sudah sesuai dengan } \\
\text { standar pelayanan MTBS }\end{array}$ & 0 & 19,4 & 66,7 & 13,9 \\
\hline $\begin{array}{l}\text { Saya mampu melakukan prosedur pelaksanaan MTBS yang sudah sesuai } \\
\text { dengan prosedur }\end{array}$ & 0 & 19,4 & 66,7 & 13,9 \\
\hline $\begin{array}{l}\text { Jumlah petugas yang ada saat ini sudah cukup untuk menangani balita } \\
\text { dalam satu hari. }\end{array}$ & 0 & 19,4 & 66,7 & 13,9 \\
\hline $\begin{array}{l}\text { Jumlah balita sakit yang saya tangani sudah sesuai dengan standar } \\
\text { pelayanan MTBS }\end{array}$ & 0 & 27,8 & 63,9 & 8,3 \\
\hline Tujuan dalam MTBS sudah sesuai & 0 & 19,4 & 63,9 & 16,7 \\
\hline $\begin{array}{l}\text { Saya selalu melakukan } \\
\text { pencatatan dan pelaporan setelah melaksanakan pelaksanaan MTBS }\end{array}$ & 0 & 8,3 & 69,4 & 22,2 \\
\hline $\begin{array}{l}\text { Jumlah balita sakit yang saya tangani kurang sesuai dengan standar } \\
\text { pelayanan MTBS }\end{array}$ & 8,3 & 44,4 & 44,4 & 2,8 \\
\hline $\begin{array}{l}\text { Saya tidak melakukan pencatatan dan pelaporan setelah melaksanakan } \\
\text { pelaksanaan MTBS }\end{array}$ & 0 & 19,4 & 63,9 & 16,7 \\
\hline
\end{tabular}


Tabel 5. diatas menunjukkan dari hasil pernyataan dengan hasil $(80,6 \%)$ responden setuju dengan mampu menjalankan program manajemen terpadu balita sakit yang sudah sesuai dengan standar pelayanan manajemen terpadu balita sakit, pada pernyataan kedua dengan hasil $(80,6 \%)$ responden setuju dengan mampu melakukan prosedur pelaksanaan manajemen terpadu balita sakit yang sudah sesuai dengan prosedur, pada pernyataan ketiga dengan hasil $(80,6 \%)$ responden setuju jumlah balita sakit yang di tangani sudah sesuai dengan standar pelayanan manajemen terpadu balita sakit, pada pernyataan jumlah petugas yang ada saat ini sudah cukup untuk menangani balita dalam satu hari, pada pernyataan ke lima dengan hasil $(80,6 \%)$ responden setuju tujuan dalam manajemen terpadu balita sakit sudah sesuai, pada pernyataan ke enam dengan hasil $(91,6 \%)$ responden setuju selalu melakukan pencatatan dan pelaporan setelah melaksanakan pelaksanaan manajemen terpadu balita sakit, pada pernyataan ke tujuh dengan hasil ( $52,7 \%)$ responden tidak setuju jumlah balita sakit yang saya tangani kurang sesuai dengan standar pekerjaan manajemen terpadu balita sakit, pada pernyataan ke delapan dengan hasil $(80,6 \%)$ responden setuju tidak melakukan pencatatan dan pelaporan setelah melaksanakan pelaksanaan manajemen terpadu balita sakit.

Tabel 6. Distribusi Frekuensi gambaran beban kerja Perawat dalam pelaksanaan MTBS berdasarkan kondisi pekerjaan di Puskesmas Wilayah Kerja Dinas Kesehatan Kabupaten Bandung

\begin{tabular}{|c|c|c|c|c|}
\hline Pernyataan & $\begin{array}{l}\text { STS } \\
(\%)\end{array}$ & $\begin{array}{l}\text { TS } \\
(\%)\end{array}$ & $\begin{array}{l}\text { S } \\
(\%)\end{array}$ & $\begin{array}{l}\text { SS } \\
(\%)\end{array}$ \\
\hline Saya kurang mampu mengatasi setiap kendala dalam menjalankan program MTBS. & 8,3 & 55,6 & 33,3 & 2,8 \\
\hline $\begin{array}{l}\text { Penerapan MTBS dilaksanakan sesuai dengan keadaan pelayanan rawat jalan di } \\
\text { pusksmas. }\end{array}$ & 0 & 5,6 & 77,8 & 16,7 \\
\hline $\begin{array}{l}\text { Beban kerja yang saya miliki dalam melaksanakan program MTBS sudah sesuai } \\
\text { dengan kemampuan saya. }\end{array}$ & 0 & 30,6 & 58,3 & 11,1 \\
\hline Beban kerja saya sehari-hari sudah sesuai dengan standar pekerjaan saya & 0 & 13,9 & 77,8 & 8,3 \\
\hline $\begin{array}{l}\text { Saya kurang cekatan dalam bekerja sehingga pelaksanaan mtbs tidak selesai tepat } \\
\text { waktu }\end{array}$ & 8,3 & 69,4 & 22,2 & 0 \\
\hline $\begin{array}{l}\text { Beban kerja yag saya miliki dalam melaksanakan program MTBS belum sesuai } \\
\text { dengan kemampuan saya. }\end{array}$ & 16,7 & 38,9 & 44,4 & 0 \\
\hline Beban kerja saya sehari-hari belum sesuai dengan standar pekerjaan saya & 5,6 & 72,2 & 22,2 & 0 \\
\hline Saya mampu menyelesaikan tugas sesuai dengan ketentuan puskesmas. & 0 & 2,8 & 77,8 & 19,4 \\
\hline Saya mampu mengatasi setiap kendala dalam menjalankan program mtbs & 0 & 27,8 & 72,2 & 0 \\
\hline
\end{tabular}

Tabel 6. di atas menunjukkan dari pernyataan pertama dengan hasil $(63,9 \%)$ responden tidak setuju dengan item kurang mampu mengatasi setiap kendala dalam menjalankan program manajemen terpadu balita sakit, pada pernyataan kedua dengan hasil $(94,5 \%)$ responden setuju penerapan manajemen terpadu balita sakit dilaksanakan sesuai dengan keadaan pelayanan rawat jalan di Puskesmas, pada pernyataan ke tiga dengan hasil $(69,4 \%)$ responden setuju beban kerja yang dimiliki dalam melaksanakan program manajemen terpadu balita sakit sudah sesuai dengan kemampuan, pada pernyataan keempat dengan hasil $(86,1 \%)$ responden setuju beban kerja sehari-hari sudah sesuai dengan standar pekerjaan, pada pernyataan ke lima dengan hasil $(77,7 \%)$ responden tidak setuju dengan item kurang cekatan dalam bekerja sehingga pelaksanaan manajemen terpadu balita sakit tidak selesai tepat waktu, pada pernyataan ke enam dengan hasil ( $55,6 \%$ ) responden tidak setuju beban kerja yang dimiliki dalam melaksanakan pelaksanaan manajemen terpadu balita sakit belum sesuai dengan kemampuan, pada pernyataan ke tujuh dengan hasil $(77,8 \%)$ responden tidak setuju beban kerja sehari-hari belum sesuai dengan standar pekerjaan, pada pernyataan kedelapan dengan hasil ( 97,2\%) 
Mustikaningsih, et al,. Beban Kerja Perawat Dalam Pelaksanaan Manajemen Terpadu Balita....

SJKP, Vol. 6, No. 1, Juni 2019, 13-24

responden setuju dengan item mampu mampu mengatasi setiap kendala dalam menyelesaikan tugas sesuai dengan ketentuan menjalankan program manajemen terpadu balita Puskesmas, pada pernyataan kesembilan dengan sakit.

hasil $(72,2 \%)$ responden setuju dengan item

Tabel 7. Distribusi Frekuensi Gambaran Beban Kerja Perawat dalam Pelaksanaan MTBS berdasarkan penggunaan waktu kerja di Puskesmas Wilayah Kerja Dinas Kesehatan Kabupaten Bandung No Pernyataan

\begin{tabular}{|c|c|c|c|c|}
\hline & $\begin{array}{l}\text { STS } \\
(\%)\end{array}$ & $\begin{array}{l}\text { TS } \\
(\%)\end{array}$ & $\begin{array}{l}S \\
(\%)\end{array}$ & $\begin{array}{l}\text { TS } \\
(\%)\end{array}$ \\
\hline $\begin{array}{l}1 \text { Waktu dalam menangani permasalahan } \\
\text { dalam mtbs sudah cukup }\end{array}$ & 0 & 30,6 & 61,1 & 8,3 \\
\hline $\begin{array}{l}2 \text { Jam kerja dalam menjalankan program mtbs } \\
\text { sudah efektif. }\end{array}$ & 0 & 19,4 & 72,2 & 8,3 \\
\hline $\begin{array}{l}3 \text { Jam kerja dalam menjalankan program mtbs } \\
\text { belum efektif }\end{array}$ & 11,1 & 58,3 & 27,8 & 2,8 \\
\hline $\begin{array}{l}4 \text { Saya kurang memanfaatkan waktu kerja saya } \\
\text { dalam menjalankan program mtbs }\end{array}$ & 11,1 & 86,1 & 2,8 & 0 \\
\hline
\end{tabular}

Tabel 7. di atas menunjukkan dari pernyataan pertama dengan hasil $(69,4 \%)$ responden setuju waktu dalam menangani permasalahan dalam manajemen terpadu balita sakit sudah cukup, pada pernyataan ke dua dengan hasil $(80,5 \%)$ responden setuju jam kerja dalam menjalankan program manajemen terpadu balita sakit sudah efektif, pada pernyataan ke tiga dengan hasil
$(69,4 \%)$ responden tidak setuju jam berapa dalam menjalankan program manajemen terpadu balita sakit belum efektif, pada pernyataan ke empat dengan hasil $(97,2 \%)$ responden tidak setuju dengan item kurang memanfaatkan waktu kerja dalam menjalankan program manajemen terpadu balita sakit.

\section{Tabel 8. Distribusi Frekuensi Gambaran Beban Kerja Perawat Dalam Pelaksanaan MTBS Berdasarkan Standar Pekerjaan Di Puskesmas Wilayah Kerja Dinas Kesehatan Kabupaten Bandung No Pernyataan}

STS TS S SS

(\%) (\%) (\%) (\%)

\begin{tabular}{clllll}
\hline 1. $\begin{array}{l}\text { Saya merasa puas dengan pencapaian saya } \\
\text { dalam menjalanka program mtsb }\end{array}$ & 0 & 33,3 & 58,3 & 8,3 \\
\hline 2. $\begin{array}{l}\text { Pelaksanaan mtbs yang saya melaksanakan } \\
\text { sudah sesuai dengan saya harapkan. }\end{array}$ & 2,8 & 36,1 & 58,3 & 2,8 \\
\hline 3. $\begin{array}{l}\text { Pelaksanaan mtbs saya laksanakan tidak } \\
\text { sesuai dengan apah yang saya harapkan. }\end{array}$ & 4,3 & 47,2 & 0 \\
\hline 4. $\begin{array}{l}\text { Saya merasa tidak puas dengan pencapaian } \\
\text { saya dalam menjalankan program mtbs }\end{array}$ & 8,3 & 47,2 & 44,4 & 0 \\
\hline
\end{tabular}

Tabel 8. di atas menunjukkan dari pernyataan pertama dengan hasil $(66,6 \%)$ responden setuju dengan item merasa puas dengan pencapaian dalam menjalankan program manajemen terpadu balita sakit, pada pernyataan ke dua dengan hasil
( 61,1\%) responden setuju pelaksanaan manajemen terpadu balita sakit yang di laksanakan sudah sesuai dengan yang diharapkan, pada pernyataan ke tigas dengan hasil $(52,7 \%)$ responden tidak setuju 
pelaksanaan manajemen terpadu balita sakit di laksanakan tidak sesuai dengan apah yang diharapkan, pada pernyataan ke empat dengan hasil $(55,5 \%)$ responden tidak setuju dengan item

Tabel 9. Distibusi Frekuensi Gambaran Beban Kerja Perawat dalam Pelaksanaan MTBS berdasarkan Target yang harus di capai di Puskesmas Wilayah Kerja Dinas Kesehatan Kabupaten Bandung

\begin{tabular}{ccc}
\hline Kategori & Frekuensi & $\%$ \\
\hline Tinggi & 10 & 27,8 \\
Sedang & 16 & 44,4 \\
Rendah & 10 & 24,8 \\
\hline Total & 36 & 100 \\
\hline
\end{tabular}

Dari tabel diatas dapat dilihat hasil penelitian terhadap responden berdasarkan beban kerja Perawat untuk taget yang harus dicapai dengan berjumlah 8 item pernyataan. Dari 36 responden yaitu 10 orang $(27,8 \%)$ sebagian dari responden dinyatakan target yang harus di capai tinggi, 16 orang $(44,4 \%)$ responden dinyatakan target yang harus dicapai sedang, dan 10 orang $(24,8 \%)$ responden dinyatakan rendah.

Tabel 10. Distibusi Frekuensi Gambaran Beban Kerja Perawat dalam Pelaksanaan MTBS berdasarkan kondisi pekerjaan di Puskesmas Wilayah Kerja Dinas Kesehatan Kabupaten Bandung

\begin{tabular}{ccc}
\hline Kategori & Frekuensi & $\%$ \\
\hline Tinggi & 17 & $47,2 \%$ \\
Sedang & 10 & $27,8 \%$ \\
Rendah & 9 & $25,0 \%$ \\
\hline Total & 36 & $100 \%$ \\
\hline
\end{tabular}

Dari tabel di atas dapat dilihat hasil penelitian terhadap responden berdasarkan beban kerja Perawat dengan kondisi pekerjaan dengan berjumlah 9 item pernyataan. Dari 36 responden yaitu 17 orang $(47,2 \%)$ sebagian dari responden dinyatakan kondisi pekerjaan nya tinggi, 10 orang $(27,8 \%)$ responden dinyatakan kondisi pekerjaannya sedang, 9 orang $(25,0 \%)$ responden dinyatakan kondisi pekerjaannya rendah.

Hasil penelitian terhadap responden berdasarkan beban kerja Perawat dengan merasa tidak puas dengan pencapaian dalam menjalankan program manajemen terpadu balita sakit.

standar pekerjaan yang berjumlah 4 item pernyataan. Dari 36 responden yaitu 14 orang $(38,9 \%)$ sebagian dari responden dinyatakan standar pekerjaan nya tinggi, 13 orang $(36,1 \%)$ responden dinyatakan standar pekerjaan sedang, 9 orang $(25,0 \%)$ responden dinyatakan standar pekerjaan rendah. (Tabel 11)

Tabel 11. Distibusi Frekuensi Gambaran Beban Kerja Perawat dalam Pelaksanaan MTBS berdasarkan Penggunaan Waktu Kerja di Puskesmas Wilayah Kerja Dinas Kesehatan Kabupaten Bandung

\begin{tabular}{ccc}
\hline Kategori & Frekuensi & $\%$ \\
\hline Tinggi & 27 & $75.0 \%$ \\
Sedang & 0 & 0 \\
Rendah & 9 & $25,0 \%$ \\
\hline Total & 36 & $100 \%$
\end{tabular}

Dari tabel di atas dapat dilihat hasil penelitian terhadap responden berdasarkan beban kerja Perawat dengan penggunaan waktu kerja berjumlah 4 item pernyataan. Dari 36 responden yaitu 27 orang $(75.0 \%)$ sebagian dari responden dinyatakan penggunaan waktu kerjanya tinggi, 9 orang $(25,0 \%)$ responden dinyatakan penggunaan waktu kerja rendah.

Tabel 12. Distibusi Frekuensi Gambaran Beban Kerja Perawat dalam Pelaksanaan MTBS berdasarkan Standar Pekerjaan di Puskesmas Wilayah Kerja Dinas Kesehatan Kabupaten Bandung

\begin{tabular}{ccc}
\hline Kategori & Frekuensi & $\%$ \\
\hline Tinggi & 14 & $38,9 \%$ \\
Sedang & 13 & $36,1 \%$ \\
Rendah & 9 & $25,0 \%$ \\
\hline Total & 36 & $100 \%$
\end{tabular}

Tabel 13. menunjukkan bahwa mayoritas responden memiliki beban kerja rendah sebanyak 13 orang sebesar (36,1\%), responden yang memiliki beban kerja sedang sebanyak 12 orang sebesar (33,3\%), dan responden yang memiliki beban kerja tinggi 
sebanyak 11 orang sebesar (30,5\%). Berdasarkan data hasil penelitian jawaban responden terhadap pertanyaan-pertanyaan variabel beban kerja sebagian besar masuk dalam kategori rendah.

Tabel 13. Distribusi Frekuensi Gambaran Beban Kerja Perawat dalam Pelaksanaan MTBS di Puskesmas Wilayah Kerja Dinas Kesehatan Kabupaten Bandung tahun 2017

\begin{tabular}{ccc}
\hline Beban kerja & Frekuensi & Persentase \\
\hline Tinggi & 11 & $30,5 \%$ \\
Sedang & 12 & $33,3 \%$ \\
Rendah & 13 & $36,1 \%$ \\
\hline Total & 36 & $100 \%$
\end{tabular}

\section{PEMBAHASAN}

Berdasarkan karakteristik responden yang didapat dari hasil penelitian ini dapat mengetahui tentang karakteristik perawat dalam pelaksanaan manajemen terpadu balita sakitdi poli. Hasil penelitian ini menunjukkan karakteristik responden yang ikut berpartisipasi dalam penelitian ini adalah perempuan.Jenis kelamin merupakan salah satu faktor yang digunakan untuk menentukan indikator atau ukuran dari perilaku. Green (1980) dalam Notoatmodjo (2010) Mengatakan bahwa jenis kelamin merupakan predisposing faktor terjadinya perubahan perilaku seseorang.

Data ini menunjukkan tidak adanya perbedaan proporsi yang signifikan antara Perawat perempuan dan laki-laki. Perbedaan jenis kelamin tidak muncul dalam perilaku yang berorientasi terhadap tugas, orang, efektifitas dari manajer actual, dan respons bawaan terhadap actual (Ivancevich, Robert, dan Michael, 2006). Meskipun pelayanan kesehatan yang diberikan harus mampu menghadirkan pelayanan yang memuaskan bagi pasien. (Notoatmodjo, 2010).

Notoatmodjo (2010) dalam Novitasari (2014) menyatakan bahwa tingkat pendidikan mempengaruhi kesadaran akan pentingnya arti kesehatan baik pada diri sendiri maupun lingkungan yang dapat mendorong kebutuhan akan pelayanan kesehatan, termasuk pelaksanaan MTBS (Manajemen Terpadu Balita Sakit). Sebagian besar Perawat berlatar belakang pendidikan Diploma 1 sebesar (13,9\%), Diploma 3 sebesar (72,2\%), Diploma 4 sebesar (13,9\%). Hal ini menunjukkan bahwa terdapat perbedaan proporsi terkait latar belakang pendidikan Perawat yang melaksanakan pelaksanaan manajemen terpadu balita sakit. Dari data di dapat Perawat yang berlatar pendidikan sudah cukup banyak, diharapkan dengan latar belakang pendidikan yang baik agar dapat meningkatkan kualitas pelayanan kesehatan.

Robbins et. Al (2008) menyatakan bahwa perilaku di masa lalu adalah dasar perkiraan paling baik dari perilaku di masa depan, hal ini terkait dengan lama atau konsisten seseorang terhadap pekerjaannya. Dari hasil pengumpulan data didapat bahwa Perawat sudah bekerja 5-10 tahun sebanyak 14 orang (38,9\%), 11-15 tahun sebanyak 5 orang sebanyak (13,9\%), 16-20 tahun sebanyak 4 orang $(11,1 \%), 21-25$ tahun sebanyak 5 orang $(13,9 \%), 26-30$ tahun sebanyak 7 orang $(19,4 \%)$, dan 31-35 tahun sebanyak 1 orang (2,8\%). Dari data tersebut diharapkan Perawat sudah mampu memberikan yang positif terhadap pelayanan pelaksanaan manajemen terpadu balita sakit.

Seniati (2006) menunjukkan adanya pengaruh lama kerja terhadap komitmen, dimana semakin lama masa kerja maka akan memiliki komitmen yang lebih tinggi. Semakin lama seseorang bekerja dalam satu organisasi maka semakin tinggi pula kepuasannya terhadap pekerjaan, hal ini diperoleh antara lain karena adanya kesesuaian antara apa yang diharapkan dengan apa yang diterima (Spector, 1997 dalam Seniati, 2006). Diharapkan Perawat mampu menjadi role model yang baik dan menjadi loyalitas yang tinggi dalam bekerja.

\section{Beban Kerja berdasarkan Target yang harus dicapai}

Hasil penelitian terhadap responden berdasarkan beban kerja perawat untuk taget yang harus dicapai. Dari 36 responden yaitu 10 orang $(27,8 \%)$ sebagian dari responden dinyatakan target yang harus di capai tinggi, 16 
orang $(44,4 \%)$ responden dinyatakan target yang harus dicapai sedang, dan 10 orang $(24,8 \%)$ responden dinyatakan rendah. Bertambahnya target yang harus dicapai, bertambah pula beban kerja pada karyawannya, menurut Setyawan dan Kuswati (2006) apabila beban kerja terus menerus bertambah tanpa adanya pembagian beban kerja yang sesuai maka kinerja karyawan akan menurun. Beban kerja merupakan salah satu unsur yang harus diperhatikan bagi seorang tenaga kerja untuk mendapatkan keserasian dan produktivitas kerja yang tinggi selain unsur beban tambahan akibat lingkungan kerja dan kapasitas kerja (Sudiharto, 2001;22).

Menurut Menpan (1997) beban kerja adalah sekumpulan atau sejumlah kegiatan yang harus diselesaikan oleh suatu organisasi atau pemegang jabatan dalam jangka waktu tertentu. Beban kerja merupakan parameter utama yang harus di perhatikan dalam upaya meningkatkan kinerja karyawan.

Beban kerja yang ada pada Perawat di Puskesmas Wilayah Kerja Dinas Kesehatan Kabupaten Bandung sangat mempengaruhi tingkat produktifitas kinerja karyawan, beban kerja harus seimbang agar petugas dapat maksimal dalam produktifitas kinerjanya. Hasil penelitian menunjukkan skor pada indikator target yang harus di capai menunjukkan skor sedang dengan $(44,4 \%)$. Beban kerja pada Perawat masih terlihat tinggi berdasarkan hasil data kuesioner yaitu pada indikator target yang harus di capai.

\section{Beban Kerja berdasarkan Kondisi Pekerjaan}

Hasil penelitian terhadap responden berdasarkan beban kerja perawat dengan kondisi pekerjaan. Dari 36 responden yaitu 17 orang $(47,2 \%)$ sebagian dari responden dinyatakan kondisi pekerjaan nya tinggi, 10 orang $(27,8 \%)$ responden dinyatakan kondisi pekerjaannya sedang, 9 orang $(25,0 \%)$ responden dinyatakan kondisi pekerjaannya rendah. Karena beban kerja berdasarkan kondisi pekerjaan dinyatakan kondisi pekerjaan nya tinggi dengan presentase $(47,2 \%)$ karena beban kerja yang dihadapinya terlalu banyak sehingga tidak mampu mengatasi setiap kendala dalam menjalankan program MTBS (Manajemen Terpadu Balita Sakit).
Menurut pendapat yang disampaikan oleh Iskandar (2012) yang menyatakan bahwa beban kerja merupakan faktor ekstrinsik individu yang menjadi salah satu sumber munculnya tekanan, karena beban kerja yang didahapinya terlalu banyak. Kondisi pekerjaan ini menuntut pegawai untuk memberikan pekerjaannya, tetapi semua ini tergantung pada masing-masing individunya, maksud nya tugas-tugas tersebut akan selesai dengan baik atau tidak tergantung bagaimana seseorang menghayati beban kerja yang dirasakannya.

Kondisi kerja yang mendukung dapat mempengaruhi dalam menyelesaikan tugas yaitu sarana dan prasarana kerja yang memadai sesuai dengan sifat tugas yang harus diselesaikan (Hamzah, 2008)

\section{Beban kerja berdasarkan penggunaan waktu kerja}

Hasil penelitian terhadap responden berdasarkan beban kerja perawat dengan penggunaan waktu kerja. Dari 36 responden yaitu 27 orang $(75.0 \%)$ sebagian dari responden dinyatakan penggunaan waktu kerjanya tinggi, 9 orang $(25,0 \%)$ responden dinyatakan penggunaan waktu kerja rendah. Hasil dari gambaran beban kerja berdasarkan penggunaan waktu kerja dinyatakan tinggi dengan presentase $(75,0 \%)$ dikarenakan petugas mampu menangani permasalahan dalam pelaksanaan manajemen terpadu balita sakit dan dapat menjalankan program manajemen terpadu balita sakit dengan efektif.

Menurut hasil penelitian Sujarwanto (2016) hasil penelitian menunjukkan bahwa beban kerja berpengaru positif dan signifikan terhadap kinerja. Pengaruh beban kerja terhadap kinerja karyawan dapat dijelaskan dengan beberapa faktor. Indikator ketaatan pada penggunaan waktu kerja memiliki skor terendah.hal ini menunjukkan bahwa penggunaan waktu kerja merupakan hal yang perlu diperhatikan oleh sebagian karyawan. Penggunaan waktu kerja merupakan hal yang sangat penting peranannya dan sangat mempengaruhi untuk meningkatkan kinerja karyawan, karena ketika penggunaan waktu kerja dengan baik maka pekerjaan mereka akan memiliki hasil yang baik karena sesuai dengan apah yang ada dalam standar yang 
sudah ditentukan. Berdasarkan observasi, masih terlihat adanya penggunaan waktu kerja kurang baik, karena masih ada karyawan yang bekerja melebihi jam kerja yang ditentukan untuk menyelesaikan pekerjaannya. Hal ini tentunya akan berpengaruh terhadap kinerja mereka, karena dengan mereka bekerja melebihi jam kerja yang ditentukan menunjukkan setiap harinya selalu ada pekerjaan yang belum terselesaikan tepat waktu, maka hal tersebut akan menunda selesainya pekerjaan lain yang semestinya mereka kerjakan. hal ini menunjukkan bahwa penting untuk memperhatikan jam kerja para karyawan untuk menggunakan waktu kerja sebaik-baiknya, karena dengan penggunaan waktu kerja yang baik dapat menyelesaikan tugas dan kewajibannya dengan tepat waktu, sehingga tidak akan lagi terjadi keterlambatan dalam pelasanaan dan penggunaan tugas dalam pekerjaan.

\section{Beban kerja berdasarkan Standar pekerjaan}

Hasil penelitian terhadap responden berdasarkan beban kerja perawat dengan standar pekerjaan. Dari 36 responden yaitu 14 orang $(38,9 \%)$ sebagian dari responden dinyatakan standar pekerjaan nya tinggi, 13 orang $(36,1 \%)$ responden dinyatakan standar pekerjaan sedang, 9 orang $(25,0 \%)$ responden dinyatakan standar pekerjaan rendah. Hasil beban kerja berdasarkan standar pekerjaan dinyatakan tinggi dengan presesntase $(38,9 \%)$ dikarenakan petugas melaksanakan pelaksanaan manajemen terpadu balita sakit sudah sesuai dengan standar pekerjaan.

Menurut Handayani (2012) hasil penelitian dimana pelaksanaan manajemen terpadu balita sakit di Puskesmas Kabupaten Kulon Progo tahun 2012 dalam penelitian tersebut sebagian besar memiliki kinerja yang baik sesuai dengan Standar Pekerjaan dan Standar pelayanan pada bagan manajemen terpadu balita sakit. Menurut Bustami (2011) menyatakan bahwa apabila standar dipenuhi, maka hasil yang diinginkan bisa tercapai.

Menurut Ika dan Neti (2016) hasil penelitian menunjukkan sebagian besar responden menilai standar pelayanan manajemen terpadu balita sakit baik. Keadaan ini dapat disebabkan karena sebagaian besar pelaksanaan manajemen terpadu balita sakit selalu melaksanakan pemeriksaan pada balita sakit sesuai dengan langkah-langkah dalam pendekatan manajemen terpadu balita sakit di Puskesmas Wilayah Kerja Dinas Kesehatan Kabupaten Bandung.

Hasil analisis menunjukan bahwa sebagian besar responden memiliki beban kerja rendah terhadap pelaksanaan manajemen terpadu balita sakitdengan 13 responden dengan presentase sebesar $36,1 \%$.

Hasil penelitian didapatkan bahwa mayoritas responden memiliki beban kerja rendah sebanyak 13 orang sebesar $(36,1 \%)$, responden yang memiliki beban kerja sedang sebanyak 12 orang sebesar $(33,3 \%)$, dan responden yang memiliki beban kerja tinggi sebanyak 11 orang sebesar (30,5\%). Berdasarkan data hasil penelitian jawaban responden terhadap pernyataan-pernyataan variabel beban kerja sebagian besar masuk dalam kategori rendah.

Menurut penelitian yang dilakukan Wahyuni (2011) Beban kerja adalah jumlah tugas pokok yang diberikan kepada responden di Puskesmas termasuk tugas pada program manajemen terpadu balita sakit. Responden dengan beban kerja ringan sebanyak 23 orang, lebih kecil bila dibandingkan proporsi responden kerja berat sebanyak 57 orang.

Beban kerja dapat dianalisi dari tuntutan tugas yang dilakukan oleh tenaga kerja. Performasi kerja sepenuhnya akan tergantung pada upaya manusia yang berperan sebagai sumber tenaga maupun pengendalian kerja. Selama kegiatan berlangsung, konsumsi energy merupakan faktor utama yang dijadikan tolak ukur penentu berat atau ringannya pekerjaan. Berat ringannya beban kerja sangat dipengaruhi oleh jenis aktivitas (sebagai beban utama) dan lingkungan kerja (sebagai beban tambahan). Peningkatan denyut nadi mempunyai peran sangat penting dalam peningkatan cardiac output dari istirahat sampai kerja maksimum (Tarwaka, 2010).

Menurut Penelitian yang dilakukan serly (2011) menunjukkan hubungan kuat yang berarti koefisien regresi gandanya signifikan dengan kombinasi antara tingkat pengetahuan tenaga kesehatan, motivasi tenaga kesehatan, dan beban kerja tenaga kesehatan berhubungan 
secara signifikan dengan penerapan manajemen terpadu balita sakit. Terdapat terdapat hubungan yang signifikan antara tingkat pengetahuan tenaga kesehatan, motivasi tenaga kesehatan, dan beban kerja tenaga kesehatan dengan mutu penerapan manajemen terpadu balita sakit. Dengan artian semakin tinggi tingkat pengetahuan tenaga kesehatan, motivasi tenaga kesehatan, maka semakin tinggi tingkat pengetahuan tenaga kesehatan, motivasi tenaga kesehatan, maka semakin tinggi pula mutu penerapan manajemen terpadu balita sakit dan semakin rendah beban kerja tenaga kesehatan maka semakin tinggi pula mutu penerapan manajemen terpadu balita sakit.

\section{KESIMPULAN DAN SARAN}

Berdasarkan hasil penelitian yang dilakukan dan data yang diperoleh di Puskesmas Wilayah Kerja Dinas Kesehatan Kabupaten Bandung mengenai beban kerja perawat dalam pelaksanaan manajemen terpadu balita sakit di Puskesmas Wilayah Kerja Dinas Kesehatan Kabupaten Bandung pada bab sebelumnya maka peneliti dapat menarik beberapa kesimpulan sebagai beriku: 1) Beban kerja berdasarkan target yang harus dicapai di Puskesmas Wilayah Kerja Dinas Kesehatan Kabupaten Bandung terdapat kategori sedang sebanyak $16(44,4 \%)$, kategori tinggi sebanyak $10(27,8 \%)$, dan kategori rendah sebanyak 10 (24,8\%). 2) Beban kerja berdasarkan kondisi pekerjaan di Puskesmas Wilayah Kerja Dinas Kesehatan Kabupaten Bandung terdapat kategori tinggi sebanyak 17 $(47,2 \%)$, kategori sedang sebanyak $10(27,8 \%)$, kategori rendah sebanyak 9 (25,0\%).3) Beban kerja berdasarkan penggunaan waktu kerja di Puskesmas Wilayah Kerja Dinas Kesehatan Kabupaten Bandung terdapat kategori tinggi sebanyak $27(75,0 \%)$, kategori rendah sebanyak 9 (25,0\%). 4) Beban kerja berdasarkan standar pekerjaan di Puskesmas Wilayah Kerja Dinas Kesehatan Kabupaten Bandung terdapat kategori tinggi sebanyak 14 (38,9\%), kategori sedang sebanyak $13(36,1 \%)$, kategori rendah 9 (25,0\%).5) Beban kerja perawat dalam pelaksanaan manajemen terpadu balita sakit) di Puskesmas Wilayah Kerja Dinas Kesehatan Kabupaten Bandung dalam kategori beban kerja rendah sebanyak 13 (36,1\%), beban kerja sedang sebanyak $12(33,3 \%)$, beban kerja tinggi sebanyak $11(30,5 \%)$.

Berdasarkan hasil penelitian, pembahasan, dan kesimpulan yang diperoleh, maka saran yang dapat diberikan sebagai berikut: 1) Berdasarkan hasil penelitian diketahui bahwa beban kerja pada indikator pencapain target yang harus di capai mendapatkan penilaian rendah. Disarankan untuk mengevaluasi kembali beban kerja yang diberikan kepada karyawannya agar mereka tidak merasa terbebani dan memperhatikan suasana kerja di ruang kerja karyawannya agar mereka lebih nyaman dalam bekerja. 2) Peneliti selanjutnya dapat mengembangkan penelitian ini dengan menggunakan metode lain dengan desain yang berbeda.

\section{DAFTAR PUSTAKA}

Depkes RI, 2011. Buku Bagan Manajemen Terpadu Balita Sakit (MTBS). Jakarta

Departemen Kesehatan RI. 1999. Informasi Manajemen Terpadu Balita Sakitakarta. Departemen Kesehatan RI. Jakarta.

Hamzah, H. 2008. Teori motivasi dan pengukurannya: analisis di bidang pendidikan. Jakarta: BT bumi Aksara.

Iskandar dan Sentot. 2012. Pengaruh beban kerjaa, motivasi dan kepuasan kerja terhadap kinerja pegawai Bank BJB cabang Padalarang. Jurnal ekonomi, Bisnis dan entrepreneurship vol. 6. ISSN 2443-0633. HAL. 26

Ivancevich, John M, Robert konopaske, Michael, T. Mantteson 2006. Perilaku dan Manajemen Organisasi. Jakarta: PT Gelora Aksana Pratama

Kementrian Kesehatan RI. 2010. Bulletin Jendela Epidemiologi 2010. Jakarta

Menpan. 1997. Definisi Beban Kerja. Http://www.bkn.go.id (diakses pada tanggal 16 juni 2017).

Notoatmojo, Soekidjo. 2010. IImu Perilaku Kesehatan. Jakarta: Rineka Cipta 
Novitasari. 2014. Hubungan Pengetahuan dan Motivasi dengan Perilaku Perawat dalam Penatalaksanaan Manajemen Terpadu Balita Sakit (MTBS) Diare di Puskesmas Kota Cilegon. Skripsi. Program Studi IImu Keperawatan Universitas Islam Negeri Syarif Hidayatullah. Jakarta.

Riskesdas Nasional. 2010, 2011, 2012, 2013.

Seniati, Liche. 2006. Makara. Pengaruh Masa Kerja, terkait kepribadian, kepuasan kerja, dan iklim Psikologis terhadap komitmen Dosen pada UI.

Setyawan, A.A., dan Kurwat, R. 2006. Tehnik Informasi dan Repormasi Fungsi Manajemen Sumber daya Manusia. Jurnal Manajemen dan Bisnis. ISSN. 1410-4571. Hal. 109.

Sujarwo. 2016. Pengaruh Motivasi kerja dan Beban kerja terhadap kinerja karyawan Bank BTN Yogyakarta. Skripsi. Universitas Negeri Yogyakarta.

Tarwaka, dkk. 2004. Ergonomi untuk Kesehatan, keselamatan Kerja dan Produktivitas. Yogyakarta: UNIBA PRESS
UNICEP, 2013. Integreted Management of the Childhood IIInes, WHO, UNICEP, Geneva.

WHO. 2005. Handbook: IMCl Integrated Management of Chilhood IIIness. Geneva, Switzerland: World Health Organization. Diakses tanggal 27 April 2014 pukul 1.54 WIB di situs: http://whqlibdoc.who.int/publications/2005 19241546441.pdf 